\title{
BINDING OF CADMIUM TO SOIL HUMIC ACID AS A FUNCTION OF CARBOXYL GROUP CONTENT
}

\author{
Tatjana Anđelković ${ }^{1 *}$, Ružica Nikolić1, Aleksandar Bojić ${ }^{1}$, Darko Anđelković2 \\ Goran Nikolić ${ }^{3}$
}

\author{
${ }^{1}$ Faculty of Science and Mathematics, University of Niš, Višegradska 33, 18000 Niš, Serbia \\ ${ }^{2}$ Water Works Association ,, Naissus “, Kneginje Ljubice 1/I, 18000 Niš \\ ${ }^{3}$ Faculty of Technology, Bulevar oslobođenja 124, University of Niš, 16000 Leskovac, Serbia \\ tatjanaan@gmail.com
}

The binding of $\mathrm{Cd}(\mathrm{II})$ to soil humic acid (HA) at $\mathrm{pH} 6.5$ and in $0.1 \mathrm{~mol} / \mathrm{L} \mathrm{KNO}_{3}$ ionic medium, was studied by potentiometric titration with a cadmium ion selective electrode. The influence of carboxyl groups in cation-humic interactions was investigated by selective blocking of humic acid carboxyl groups with thionyl chloride and methanol. Infrared spectroscopic analysis confirmed that esterification took place. Differences between underivatized and derivatized HA complexation properties are ascribed to carboxyl groups. The Scatchard plots and incremental formation constants were used to obtain values for Cd-binding constants, for both HAs. The derivatization decreased the number of HA complexing sites by approximately $60 \%$, which correlates with acid-base properties of both HAs, studied by barium hydroxide and calcium acetate exchange methods. The stability constants for binding at the strongest sites $\left(\log K_{\mathrm{INT}}\right)$ was larger for underivatized HA (5.40) than for derivatized HA (4.92), indicating greater stability in the case when carboxyl groups are involved in complexation reaction.

Key words: cadmium; humic acid; carboxyl group content; Scatchard plot; ion-selective electrode

\section{ВЛИЈАНИЕ НА СОДРЖИНАТА НА КАРБОКСИЛНИТЕ ГРУПИ ВРЗ ВРЗУВАЫЕТО НА Сd(II) ЗА СОЛИ НА ХУМИНСКАТА КИСЕЛИНА ОД ПОЧВАТА}

Врзувањето на $\mathrm{Cd}(\mathrm{II})$ за хуминската киселина од почвата при $\mathrm{pH} 6,5$ во $0,1 \mathrm{~mol} / \mathrm{L}$ јонски медиум на $\mathrm{KNO}_{3}$ беше изучувано со потенциометриска титрација со примена на јон селективна електрода за кадмиум. За да се испита влијанието на карбоксилните групи во катјон-хумински интеракции, карбоксилните групи беа селективно блокирани по пат на естерификација со тионилхлорид и метанол. Естерификацијата на карбоксилните групи беше потврдена со примена на инфрацрвена анализа. Разликите помеѓу особините на комплексирање на дериватизираните и недериватизираните хумински киселини се должат на присуството на карбонилни групи. Графичкиот приказ и константите на формирање на комплекси се искористени за да се добијат вредностите на константите на сврзување за Сd со двете хумински киселини.

Клучни зборови: кадмиум; хуминска киселина; содржина на карбоксилни групи; Скачардов графикон; јон-селективна електрода 


\section{INTRODUCTION}

Nowadays, the interest in humic substances (HS) research, is obvious from the role they play in a range of environmental issues, such as soil and water acidification, nutrient control, weathering, soil formation, soil structure, mobility and distribution of heavy metals, radioactive waste disposal, pesticides, xenobiotics, ecosystem buffering, etc. [1]. In almost all of those issues, cation binding is recognised to be an important factor. Even though there are many papers dealing with cation-humic interactions [2-5], there is still some uncertity about how humic functional group heterogeneity affects proton and metal binding [6].

It is well known that HS are too heterogeneous in nature. They are considered as polydisperse mixtures of natural organic polyelectrolytes, containing a large number of different functional groups [7]. The ability of humic acids to form stable complexes with polyvalent cations is attributed to their high content of oxygen-containing functional groups including carboxyl, phenol, hydroxyl, enol and carbonyl structures of various types [8]. The most important cation-humic interactions involve both phenol and carboxyl groups, while reactions of less importance involve only carboxyl groups $[9,10]$. Bearing in mind the fact that cation-humic interactions depend on the presence of reactive acidic functional groups, such as carboxylic and phenolic groups [11], their characterization and quantification can provide a guide to modeling metal-humate interactions.

There are various analytical methods for determination of HA oxygen-containing functional groups, such as direct and indirect potentiometric titrations [12], radiometric determination [13], infrared spectroscopy [14], carbon-13 nuclear magnetic resonance spectroscopy $\left({ }^{13} \mathrm{C}\right.$ NMR) [15], ${ }^{29} \mathrm{Si}-\mathrm{NMR}$ [16]. Beside those methods, some authors studied the differentiation between various hydroxyl groups of HA by ${ }^{13} \mathrm{C}$ NMR spectroscopy using methylated HS [17]. This modification process that resulted in HA with selectively blocked functional groups, can be used for metal ion-humic binding studies.

Even though, it is known that HS carboxyl groups play a prominent role in the complexing of cadmium ions [18, 19], no reports have appeared on derivatization of those groups in order to estimate their effect on cadmium binding. This can be achieved by selective blocking of HA carboxyl groups which would prevent their contribution to the complexation reaction. Obtained derivatized HA, with blocked carboxyl groups, could be used in comparison to underivatized HA, for investigation of the influence of carboxyl functional groups on the HA complexation properties.

In this context, selective blocking of carboxyl groups could be achieved by their esterification. Among many derivatization methods described in the literature [20], probablly one of the most atractive and efficient is the methanol/ thionyl chloride procedure [20-23], which was modified and is thus described later in detail. The applied methanol/thionyl chloride procedure is efficient route for synthesis of methyl esters of substituted aromatic carboxylic acids without affection of phenolic hydroxy groups [23]. Due to its high selectivity, the method was suitable for functionally very heterogeneous humic macromolecule.

Ion-selective electrode (ISE) for cadmium was used to measure $\mathrm{Cd}$ complexation. The ISE experimental technique has been shown to be a reliable for measuring $\mathrm{Cd}$ concentrations in the range $10^{-7}$ to $10^{-2} \mathrm{~mol} / \mathrm{L} \mathrm{Cd}$ in a complex organic matrix [24-27]. A number of modeling approaches have been developed to describe binding of metals by humic material [28, 29]. One of them which is basically graphical technique, the Scatchard approach $[30,31]$ is used in this study. Discrete site ligand model of humatemetal binding used in the study (the "Scatchard model") merely provide a convenient mean to mimic the observed metal binding capabilities of humic material. Even though, the ligands in the discrete ligand model may not represent actual binding sites, this model can successfully 
predict metal ion binding by humic material in the absence of competing ions (protons excluded) and within the range of the conditions of the calibrating titrations. The model should not be used to extrapolate outside the range of calibrating titrations because the postulated ligands are justified only by their ability to provide an empirical fit of available data.

Heterogeneity of humic substances and possibilty that cation binding to humic substances may also occur as a result of counter-ion accumulation to the negative charge of the humic, suggests that a large number of site types are involved in metal binding and that these site types are best characterized by a continuous distribution models (Gaussian normal distribution model [32], The Stockholm Humic Model [33], NICA-Donnan model [34]).

The choice of whether discrete or continuous model to employ in the description of metal-humate binding depends on the objective of the data analysis. The disrete ligand approach is easily adapted to experimental data using graphical methods and fitting parameters that are varied until the experimental data are appropriately described. In cases when one deals with unknown nature of humic substances, an "average" approach may be employed if it provides an adequate representation of the results. Considering the fact that the Scatchard approach shows some limitations, the Incremental Stability Constants model [35] was applied, as well. In this model, instead of calculating an average value of stability constant from a slope of the Scatchard plot, incremental stability constants from successive slope values were obtained for each point in the Scatchard plot. The intrinsic constant, $\mathrm{K}_{\mathrm{INT}}$, was obtained by extrapolation. This constant represents the metal binding at the lowest $\mathrm{Cd}$ concentration, thus describing the strongest binding site [3]. This approach is more promising than the Scatchard approach, since it expresses the HS heterogenity.

The objectives of the study presented in this paper are: evaluation of differences in carboxyl group content between underivatized and derivatized HA, quantification of the complexation of $\mathrm{Cd}$ and estimation of the strength of $\mathrm{Cd}$ binding due to the number of available carboxylic complexation sites.

\section{EXPERIMENTAL}

\subsection{Extraction and purification of humic acid}

HA was obtained following the procedure suggested by the International Humic Substances Society (IHSS) [36] from a wellhumified organic horizon of old beech-forest soil (10 cm depth), in autumn 2003, using standard grinding equipment. The soil was airdried and sieved to pass a $2.0 \mathrm{~mm}$ sieve. Briefly, $\mathrm{HA}$ was extracted from the soil with $0.1 \mathrm{~mol} / \mathrm{L}$ $\mathrm{NaOH}$ at 1:10 solid to solution (mass/volume) ratio under $\mathrm{N}_{2}$ for 4 hours. The suspension was then centrifuged at $4500 \mathrm{rpm}$ for $30 \mathrm{~min}$, the supernatant was acidified with $6 \mathrm{~mol} / \mathrm{L} \mathrm{HCl}$ to $\mathrm{pH} 1.0$ and suspension was allowed to stand overnight. Precipitated HA was separated from fulvic acid by centrifugation at $4500 \mathrm{rpm}$ for 30 min. Obtained HA precipitate was redissolved in $0.1 \mathrm{~mol} / \mathrm{L} \mathrm{KOH}$, under $\mathrm{N}_{2}$. Solid $\mathrm{KCl}$ was added to attain $0.3 \mathrm{~mol} / \mathrm{L}\left(\mathrm{K}^{+}\right)$and then suspension was centrifuged at high speed to remove suspended solids. The HA was reprecipitated with $6 \mathrm{~mol} / \mathrm{L} \mathrm{HCl}$ to $\mathrm{pH} 1.0$. The HA precipitate was suspended in a solution of $0.1 \mathrm{~mol} / \mathrm{L}$ $\mathrm{HCl} / 0.3 \mathrm{~mol} / \mathrm{L} \mathrm{HF}$. In order to minimize the ash content, this procedure was repeated three times. The acid was than dialyzed against distilled water until $\mathrm{Cl}^{-}$was eliminated. Bound metal ions were removed by putting the HA solution (at $\mathrm{pH} 8$ adjusted with $0.1 \mathrm{~mol} / \mathrm{L} \mathrm{NaOH}$ ) into a $300 \times 10 \mathrm{~mm}$ column with ion-exchange resin Dowex 50W-X8 $\left(\mathrm{H}^{+}\right.$-form) at a flow rate of $0.5 \mathrm{~mL} \mathrm{~min}^{-1}$. The protonated HA was diluted in a volumetric flask and stored at $4^{\circ} \mathrm{C}$. The concentration of the stock was determined as 1 $\mathrm{g} / \mathrm{L}$, by dry weight of measured volume of well homogenized HA suspension and stored in the dark, at $4{ }^{\circ} \mathrm{C}$. 


\subsection{Complexometric titrations}

Complexometric titrations were performed with two Hach sension $3 \mathrm{pH} /$ ion-meters; one of them was used for $\mathrm{pH}$ measurements and the other was used with an ion selective electrode (ISE-Metrohm, 6.0502.110) for Cd(II) against an double junction $\mathrm{Ag} / \mathrm{AgCl}$ reference electrode (Metrohm, 6.0726.100) filled with 3 $\mathrm{mol} / \mathrm{L} \mathrm{KCl}$ in the inner and the outer compartment. For $\mathrm{pH}$ monitoring a Hach gel-filled combination glass electrode (51935-00) was used. ISE electrode was conditioned before use by polishing, followed by immersion in $0.1 \mathrm{~mol} / \mathrm{L}$ $\mathrm{Cd}\left(\mathrm{NO}_{3}\right)_{2}$ solution, overnight, while reference electrode was conditioned by soaking in 0.1 $\mathrm{mol} / \mathrm{L}$ solution of the ionic strength adjuster.

Both electrodes were calibrated before use. Calibration of the $\mathrm{Cd}$ electrode was performed with $\mathrm{Cd}\left(\mathrm{NO}_{3}\right)_{2}$ at a concentration of $10^{-7}$ to $10^{-3} \mathrm{~mol} / \mathrm{L} \mathrm{Cd}$ and the measured electrode voltage was linear to $\mathrm{Cd}$ concentrations with a Nernstian slope $(29 \mathrm{mV})$. The calibration was performed immediately before humic acid titration. Each experiment was run three times to ensure the reproducibility.

Throughout the titrations a $\mathrm{N}_{2}$ gas was initially bubbled through the solution and then a constant atmosphere was maintained above the solution which was thermostated in a water bath at $25.0 \pm 0.1^{\circ} \mathrm{C}$. The $\mathrm{pH}$ of the solution was adjusted to $6.50 \pm 0.05$, by addition of minute amounts of diluted $\mathrm{KOH}$ or $\mathrm{HNO}_{3}$ after each addition of $\mathrm{Cd}^{2+}$ solution, as needed. Titrations were performed with $40.00 \mathrm{~mL}$ of humic acid suspension with concentration $980 \mathrm{mg} / \mathrm{L}$, titrated with $5.19 \cdot 10^{-4} \mathrm{~mol} / \mathrm{L} \mathrm{Cd}^{2+}$ in ionic medium of $0.1 \mathrm{~mol} / \mathrm{L} \mathrm{KNO}_{3}$. The potential was read only when its variation was smaller than $0.555 \mathrm{mV} /$ min, which was monitored by the drift control of the ion-meter.

The same set of experimental conditions was applied for complexometric titration of esterified humic acid.

\subsection{Esterification of $H A$}

Selective blocking of carboxyl functional groups was achieved by esterification, by isolation of esterified HA derivative (EHA). Esterification was performed by the methanol/ thionyl chloride procedure suggested by Schnitzer and Skinner [21] and Hosangadi and Dave [23]. The synthesis of derivatized humic acid is shown in the reaction scheme (Figure 1). To a stirred solution of $500 \mathrm{mg}$ of HA in $20 \mathrm{~mL}$ of methanol, under ice-cooling (approximately $\left.-5{ }^{\circ} \mathrm{C}\right)$, thionyl chloride $(5 \mathrm{~mL})$ was added dropwise from a dropping funnel, over 2 hours. The reaction mixture was then heated on the water bath for 5 minutes to decompose excess thionyl chloride. The suspension obtained was centrifuged at $2000 \mathrm{rpm}$ and the separated ester was washed with distilled water until free of chlorides. The ester was dried in a rotary evaporator and finally in a vacuum desiccator over $\mathrm{P}_{2} \mathrm{O}_{5}$. The esterification procedure was repeated and the obtained twice esterified product was marked as EHA. The obtained ester in the second esterification procedure was diluted with distilled water and the concentration of the stock EHA suspension was determined to be $1 \mathrm{~g} / \mathrm{L}$.

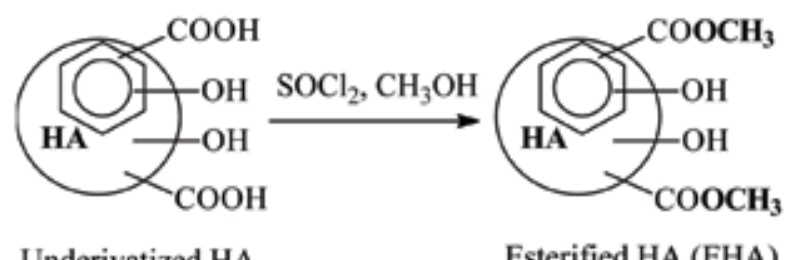

Underivatized $\mathrm{HA}$

Esterified HA (EHA)

Fig. 1. Reaction scheme for the synthesis of derivatized humic acid

\subsection{Spectrophotometric characterization of derivatized and underivatized $H A$}

IR-spectra were recorded on a Bomem Hartman \& Braun MB-Series FT-IR spectrometer from 4000 to $1000 \mathrm{~cm}^{-1}$, using $\mathrm{KBr}$ pellet (1 mg of each sample $+200 \mathrm{mg}$ of dry $\mathrm{KBr}$ ). 


\subsection{Determination of HA functional groups}

Total acidity $\left[\mathrm{Ba}(\mathrm{OH})_{2}\right.$ method $]$ and carboxylic acidity $\left[\mathrm{Ca}(\mathrm{OAc})_{2}\right.$ method] were determined according to Schnitzer and Gupta [37]. Phenolic acidity was determined by difference between total and carboxylic acidity.

\subsection{Potentiometric data evaluation}

Interactions between metal ions and macromolecules are well described by the discrete site model proposed by Scatchard [30]. This model assumes that macromolecule posses a small number of different complexing sites with no interaction among them. The charge at the macromolecule should be constant and stoichiometry of the complex is $1: 1$. Organic ligand-humic macromolecule (HA) is considered as the central group which reacts with metal $\left(\mathrm{Cd}^{2+}\right)$ giving complexes $\mathrm{CdA}, \mathrm{Cd}_{2} \mathrm{~A}$, $\ldots, \mathrm{Cd}_{\mathrm{n}} \mathrm{A}$. Successive formation constants can be described as:

$$
K_{1}=\frac{c(\mathrm{CdA})}{c(\mathrm{HA}) \cdot c\left(\mathrm{Cd}^{2+}\right)} ; K_{2}=\frac{c\left(\mathrm{Cd}_{2} \mathrm{~A}\right)}{c(\mathrm{CdA}) \cdot c\left(\mathrm{Cd}^{2+}\right)}
$$

and overall:

$$
K_{\mathrm{n}}=\frac{c\left(\mathrm{Cd}_{\mathrm{n}} \mathrm{A}\right)}{c\left(\mathrm{Cd}_{\mathrm{n}-1} \mathrm{~A}\right) \cdot c\left(\mathrm{Cd}^{2+}\right)}
$$

For binding at identical and independent sites, the Scatchard plot, $c(\mathrm{CdA}) / c\left(\mathrm{Cd}^{2+}\right)$ vs. $c(\mathrm{CdA})$ is obtained by plotting the equation:

$$
\frac{c(\mathrm{CdA})}{c\left(\mathrm{Cd}^{2+}\right)}=C_{\mathrm{C}} \cdot K-c(\mathrm{CdA}) \cdot K
$$

where $c(\mathrm{CdA})$ is the concentration of the complexed metal in $\mathrm{mol} / \mathrm{L}$, obtained from the mass balance: $c(\mathrm{CdA})=c\left(\mathrm{Cd}^{2+}\right)_{\mathrm{T}}-c\left(\mathrm{Cd}^{2+}\right)$, $c\left(\mathrm{Cd}^{2+}\right)$ is the concentration of free metal in $\mathrm{mol} / \mathrm{L}$ and $c\left(\mathrm{Cd}^{2+}\right)_{\mathrm{T}}$ is the concentration of total $\mathrm{Cd}$ equivalent to the amount of $\mathrm{Cd}$ added to the vessel in mol/L, $C_{\mathrm{C}}$ is complexing capacity (total concentration of binding sites) and $K$ is the average equilibrium constant. This equation yields average stability constant $K$ as the slope and $C_{\mathrm{C}}$ as y-axis intercept divided by the slope.

The Scatchard plot of HA is curvelinear, due to heterogeneity of its binding sites [3840]. Incremental stability constants, $\log K_{\mathrm{i}}$, were obtained as successive slopes calculated from neighboring data points in the Scatchard plot. Those constants are related to data points $[\mathrm{CdA}]_{\mathrm{SR}}$, which are equidistant between the original data points of the Scatchard plot. A plot of $\mathrm{pK}_{\mathrm{i}}\left(\log \mathrm{K}_{\mathrm{i}}\right)$ vs. $[\mathrm{CdA}]_{\mathrm{SR}}$ shows the range of strengths of binding sites. Intrinsic constants, $\mathrm{K}_{\mathrm{INT}}$, were obtained by third-degree polynomial fitting of data from $\mathrm{pK}_{\mathrm{i}}$ vs. $[\mathrm{CdA}]_{\mathrm{SR}}$ plot and by extrapolation toward $[\mathrm{CdA}]_{\mathrm{SR}}=0$ using Microcal Origin ${ }^{\circledR}$ software.

\section{RESULTS AND DISCUSSION}

Evidence that esterification of the carboxyl groups had occurred was gained by differences in the IR absorption before and after derivatization. There are two important IR regions related to this study: (1) 3200-3600 $\mathrm{cm}^{-1}$ region, characteristic for absorption due to $\mathrm{O}-\mathrm{H}$ stretching vibrations in carboxyl, phenol and hydroxyl groups and (2) 1100-1450 $\mathrm{cm}^{-1}$ region, characteristic for absorption due to $\mathrm{C}-\mathrm{O}$ stretching vibrations. The spectrum of HA showed a broad and strong peak at about 3430 $\mathrm{cm}^{-1}$ (Figure 2). In the spectra of esterified HA, there was reduction in $\mathrm{O}-\mathrm{H}$ stretching vibrations, since less hydroxyl groups were present. Also, the $\mathrm{C}-\mathrm{O}$ absorption (region $1100 \mathrm{~cm}^{-1}$ ) increased in esterified humic acid due to the formation of methyl ester (Figure 2). Higher $\mathrm{OCH}_{3}$ content of esterified derivative was indicated by strong bands for $\mathrm{C}-\mathrm{H}$ stretching at 2920 and 2850 $\mathrm{cm}^{-1}$. Esterification also increased the intensity of the $1722 \mathrm{~cm}^{-1}$ band and reduced absorption at $1622 \mathrm{~cm}^{-1}$. Intensification of the $1722 \mathrm{~cm}^{-1}$ band confirmed the conversion of carboxyl group to ester because carbonyl groups of esters absorb within a narrower range than carboxylic acids, thereby giving a more pronounced maximum [41]. The $1600 \mathrm{~cm}^{-1}$ band in HA is at least in 
part due to the antisymmetrical stretching mode of carboxylate groups. Following esterification absorption of these groups, which are converted to esters, shifts from 1600 to $1700 \mathrm{~cm}^{-1}$ [21]. The assumption was made that during esterification procedure only carboxyl groups and not phenolic groups were modified. This is based on the literature findings [23] that the esterification method is highly selective, thus do not affect phenolic hydroxy groups, and that infrared spectroscopic analysis confirmed that esterification of the humic acid did occured. Thus, the functional group content of both HAs, as well as, their complexation properties were compared.

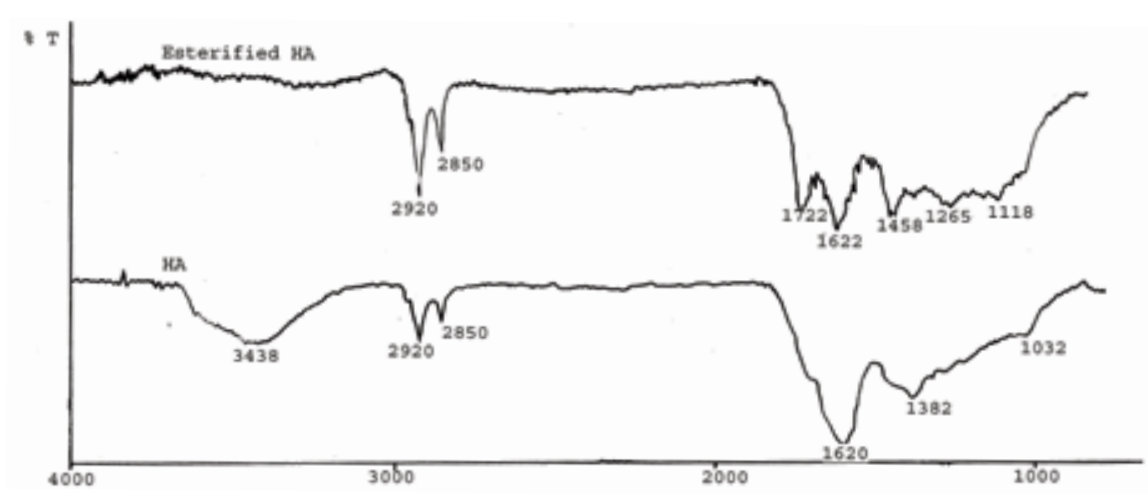

Fig. 2. FT-IR spectra of the humic acid (down) and esterified humic acid (up) in KBr pellet humic acid

The $C_{\mathrm{C}}$ values for each humic acid, obtained by the Scatchard plot are shown in Table 1 . The capacity of compost and sediment $\mathrm{HA}$ for Cd binding, as reported by Kaschl et al. [39] and Abate and Masini [27] were in the same range as obtained results for the soil HA.

The Scatchard plots for underivatized and derivatized HAs (Figures 3 and 4) were curvelinear, as it was expected due to a range of binding sites with different binding energies and variety of electrostatic and conformational changes on the humic macromolecule $[3,27$, $35,42,43]$.

Obtained average values for conditional stability constant $(\log K)$ from the Scatchard plots are shown in Table 1. Stability constants values were compared with the literature data $[25,27,39]$ and obtained values were found to be in the range of published results. Underivatized acid formed more stable complex, due to availability of carboxyl groups in complexation and chelation reactions.

The total concentration of binding sites was $0.980 \mathrm{mmol} / \mathrm{g}$ for HA and $0.425 \mathrm{mmol} / \mathrm{g}$ for EHA, which indicates that $59.8 \%$ of humic acid metal binding sites can be attributed to carboxyl groups. This result obtained by the Scatchard plot is confirmed by the barium hydroxide and calcium acetate methods for total and carboxylic acidity determination. According to the obtained values of total acidity for HA and EHA (Table 1), $58.1 \%$ of humic acid proton binding sites can also be attributed to the carboxyl groups. Considering that very similar percentage (59.8 and $58.1 \%$ ) of $\mathrm{COOH}$ groups is involved in cadmium and in proton binding, our findings suggest that there is correlation between complexing capacities and carboxyl acidity in humic acid. Due to this correlation one can predict Cd-complexation capacity of HA on the base of $\mathrm{COOH}$ group content. The estimated value of $\mathrm{COOH}$ groups content $(58.1 \%)$ is in accordance with the value obtained by $\mathrm{COOH}$ content determination with calcium actetate method applied on underivatized $\mathrm{HA}$, that is $2.80 \mathrm{mmol} / \mathrm{g}$ or $60 \%$ of total acidity. Obtained values are consistent with view that roughly $50 \%$ of humic acid acidity is due to carboxyl moieties [10]. 
In derivatized HA only $10 \%$ of ionizable groups correspond to carboxyls. This result confirms high selectivity of the methanol/ thionyl chloride derivatization procedure $(93 \%$ of carboxyl groups in HA were blocked by the method).

The values of the total concentration of binding sites and conditional stability constants were directly related to availability of carboxylic groups for interaction with ions, indicating their importance in complexation.

Incremental stability constants $\left(\mathrm{pK}_{\mathrm{i}}\right)$ for $\mathrm{Cd}$ binding by underivatized and derivatized HA are shown in Figures 5 and 6. Third-degree polynomial fit was satisfactory, thus the strongest binding sites for $\mathrm{Cd}\left(\mathrm{pK}_{\mathrm{INT}}\right)$ at low ratios of $\mathrm{Cd}$ to ligand were obtained (Table 1). The stronger binding for $\mathrm{Cd}$ was found on underivatized humic acid $\left(\mathrm{pK}_{\mathrm{INT}}=5.40\right)$ than on esterified humic acid $\left(\mathrm{pK}_{\mathrm{INT}}=4.92\right)$, indicating greater stability in the case when carboxyl groups are involved in complexation reaction. Graphs relating $\log \mathrm{K}_{\mathrm{i}}$ against $[\mathrm{Cd}]_{\mathrm{SR}}$ (Figures 5 and 6) showed decrease of incremental stability constants, due to accumulation of charge on macromolecule and thus decreasing tendency of functional groups to complex further metal ions [38].

T a ble 1

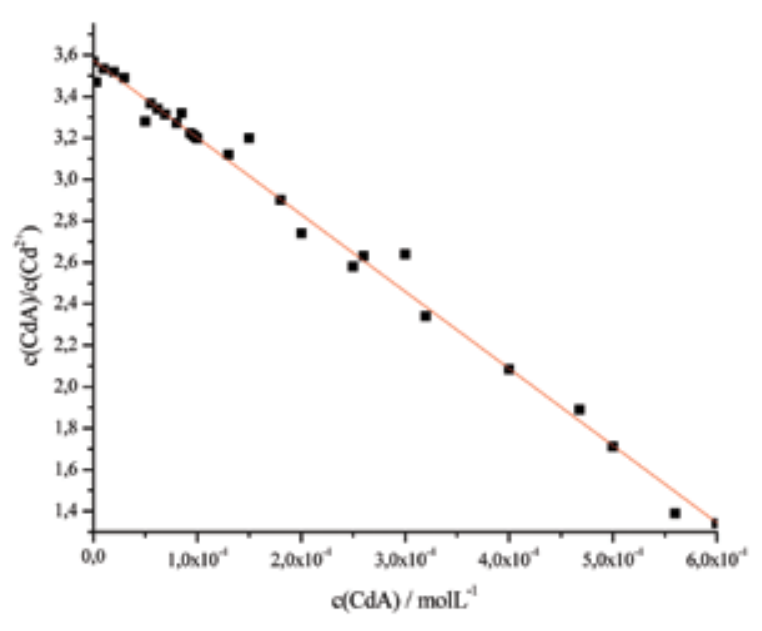

Fig. 3. Scatchard plot obtained for underivatized humic acid $(40.00 \mathrm{~mL}$ of $980 \mathrm{mg} / \mathrm{LHA}$ suspension, $\mathrm{pH}=6.50 \pm$ $0.05,0.1 \mathrm{~mol} / \mathrm{L} \mathrm{KNO}_{3}$ titrated with $5.19 \cdot 10^{-4} \mathrm{~mol} / \mathrm{L} \mathrm{Cd}^{2+}$ )

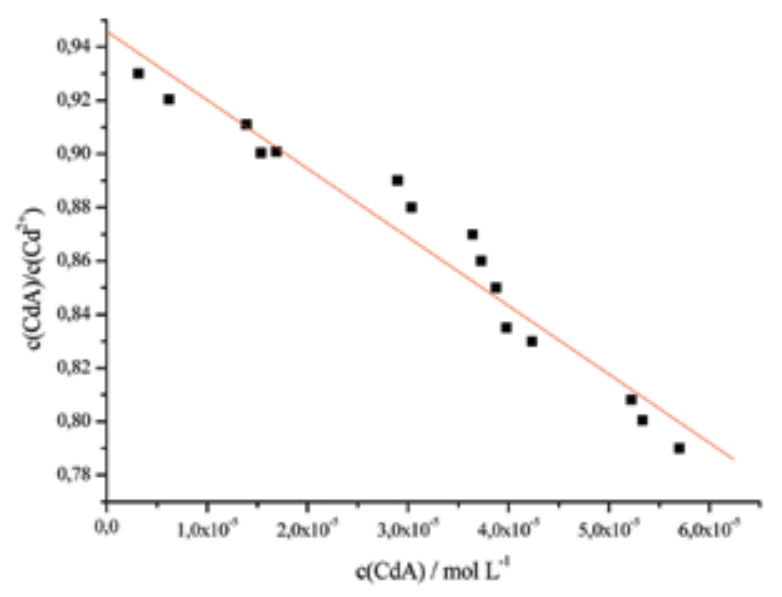

Fig. 4. Scatchard plot obtained for esterified humic acid (40.00 $\mathrm{mL}$ of $980 \mathrm{mg} / \mathrm{LEHA}$ suspension, $\mathrm{pH}=6.50 \pm$ $0.05,0.1 \mathrm{~mol} / \mathrm{L} \mathrm{KNO}_{3}$ titrated with $5.19 \cdot 10^{-4} \mathrm{~mol} / \mathrm{L} \mathrm{Cd}^{2+}$ )

Conditional stability constants $(K)$ and complexing capacities $\left(C_{C}\right)$ for the underivatized and derivatized humic acids at $25 \pm 0.1{ }^{\circ} \mathrm{C}, \mathrm{pH}=6.50 \pm 0.05$ and ionic medium of $0.1 \mathrm{~mol} / \mathrm{L} \mathrm{KNO}_{3}$ obtained according to Scatchard plots (obtained results from triplicate experiments)

\begin{tabular}{lll}
\hline \hline & HA & Derivatized HA \\
\hline $\log \mathrm{K}$ & $3.57 \pm 0.1$ & $3.35 \pm 0.1$ \\
$\mathrm{C}_{\mathrm{C}}(\mathrm{mmol} / \mathrm{g})$ & $0.980 \pm 0.1$ & $0.425 \pm 0.05$ \\
Phenolic OH $(\mathrm{mmol} / \mathrm{g})$ & 1.88 & 1.76 \\
$\mathrm{COOH}(\mathrm{mmol} / \mathrm{g})$ & 2.80 & 0.2 \\
Total acidity $(\mathrm{mmol} / \mathrm{g})$ & 4.68 & 1.96 \\
$\mathrm{pK}_{\mathrm{INT}}\left(\mathrm{R}^{2}\right)$ & $5.40(0.70)$ & $4.92(0.72)$ \\
\hline \hline
\end{tabular}




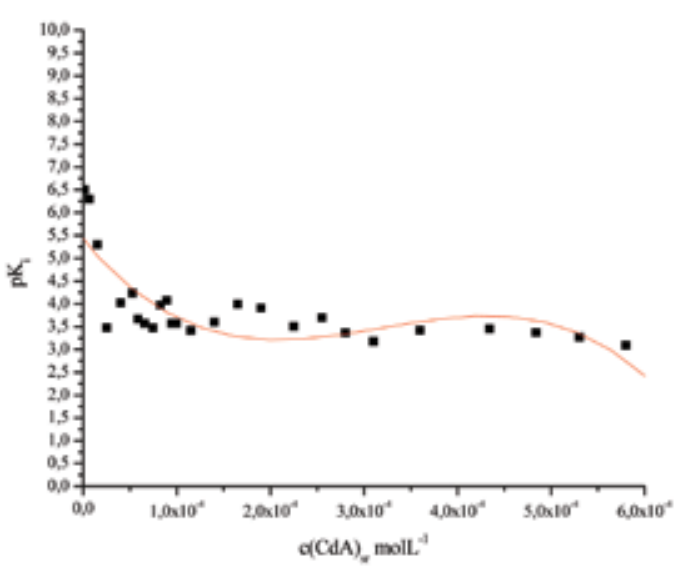

Fig. 5. Plot relating $\log K_{i}$ of Cd(II)-humic acid

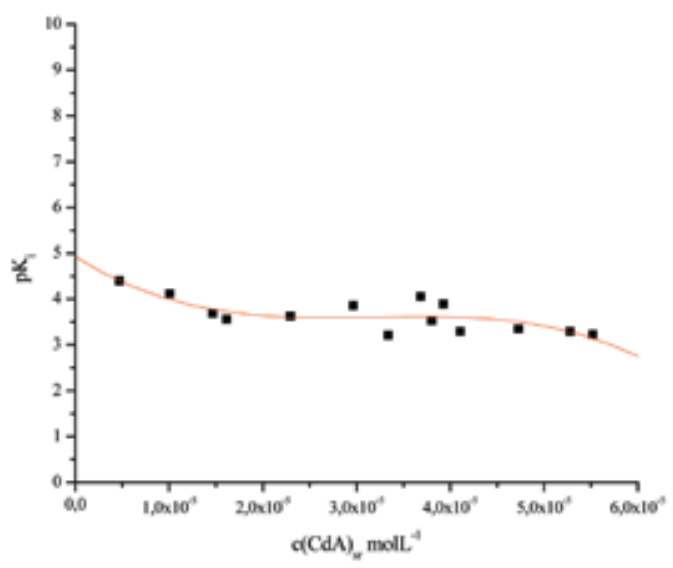

Fig. 6 . Plot relating $\log K_{i}$ of $\mathrm{Cd}(\mathrm{II})$-esterified humic acid

\section{CONCLUSION}

This study revealed that chemically modified HA by methanol/thionyl chloride esterification procedure can be used in comparison to unmodified HA for investigation of the influence of carboxyl functional groups in HA on the humic proton/metal interactions. IR spectroscopic analysis confirmed that carboxyl groups had been esterified. Selectivity of the derivatization method was confirmed by carboxyl group content determination by calcium acetate method since it was indicated that $93 \%$ of carboxyl groups in humic acid were blocked by the method.

Cadmium used in this study, showed a tendency to preferably associate with unmodified HA, due to higher content of carboxyl groups available for cadmium interaction. The values of the total concentration of binding sites and conditional stability constants were directly related to availability of carboxylic groups for interaction with ions, indicating their importance in complexation. Unmodified HA showed higher capacity for binding and existance of ionizable groups for stronger Cd-binding. Thus, approximately $60 \%$ of humic acid metal and proton binding sites can be attributed to carboxyl groups. There is direct correlation between the amount of carboxyl groups and Cd-complexing capacity, that can be used in HA complexometric properties prediction.

The binding constant was larger for underivatized HA (5.40) than for derivatized HA (4.92), indicating greater stability in the case when carboxyl groups are involved in complexation reaction.

Acknowledgements: This study was supported by the Ministry of Science and Technological Development of Serbia. The authors thank to Emilija Georgijevska for providing summary in Macedonian.

\section{REFERENCES}

[1] E. Tipping, Cation binding by humic substances, Cambridge University Press, Cambridge, 2002.

[2] J. A. Marinsky, J. Ephraim, A unified physicochemical description of the protonation and metal ion complexation equilibria of natural organic acids (humic and fulvic acids). 1. Analysis of the influence of polyelectrolyte properties on protonation equilibria in ionic media: Fundamental concepts, Environ. Sci. Technol., 20, 349-354 (1986).

[3] F. J. Stevenson, Humus chemistry: Genesis, composition, reactions, John Wiley \& Sons, New York, 1994.

[4] A. E. Martell, R. D. Hancock, Metal Complexes in Aqueous Solutions, Kluwer, New York, 1996.

[5] I. Christl, C. J. Milne, D. G. Kinniburgh, R. Kretzchmar, Relating ion binding by fulvic and humic acids to chemical composition and molecular size. 2. Metal binding, Environ. Sci. Technol., 35, 2515-2517 (2001).

[6] I. Christl, R. Kretzmar, Relating ion binding by fulvic and humic acids to chemical composition and molecular size. 1. Proton binding, Environ. Sci. Technol., 35, 2505-2511 (2001). 
[7] M. F. Benedetti, W. H. van Riemsdijk, L. K. Koopal, Humic substances considered as a heterogeneous Donnan gel phase, Environ. Sci. Technol., 30, 1805-1813 (1996).

[8] F. J. Stevenson, Geochemistry of soil humic substances, in: Humic substances in soil, sediment and water, G. R. Aiken, D. M. McKnight, R. L. Wershaw, P. MacCarthy (Eds.), Wiley, New York, 1985, pp. 13-52.

[9] M. Schnitzer, Reaction between fulvic acid, a soil humic compound and inorganic soil constituents, Soil Sci. Soc. Am. Proc., 33, 75-81 (1969).

[10] D. S. Gamble, M. Schnitzer, I. Hoffman, Cu-fulvic acid chelation equilibrium in $0.1 \mathrm{M} \mathrm{KCl}$ at $25.0^{\circ} \mathrm{C}$, Can. J. Chem., 48, 3197-32 (1970).

[11] J. C. Masini, G. Abate, E. C. Lima, L. C. Hahn, M. S. Nakurama, J. Lichtig, H. R. Nagatomy, Comparison of methodologies for determination of carboxylic and phenolic groups in humic acids, Anal. Chim. Acta, 364, 223-233 (1998).

[12] Perdue, E. M., Acidic functional groups in humic substances, in: Humic substances in soil, sediment and water, G. R. Aiken, D. M. McKnight, R. L. Wershaw, P. MacCarthy (Eds.), Wiley, New York, 1985, pp. 493-526.

[13] S. Pompe, M. Bubner, M. A. Denecke, T. Reich, A. Brachmann, G. Geipel, R. Nicolai, K. H. Heise, H. Nitsche, A comparison of natural humic acids with synthetic humic acid model substances: characterization and interaction with uranium (VI), Radiochim. Acta, 74, 135-140 (1996).

[14] P. MacCarthy, J. A. Rice, Spectroscopic methods (other than NMR) for determining functionality in humic substances, in: Humic substances in soil, sediment and water, G. R. Aiken, D. M. McKnight, R. L. Wershaw, P. MacCarthy (Eds.), Wiley, New York, 1985, pp. 527-559.

[15] R. L. Wershaw, Application of nuclear magnetic resonance spectroscopy for determining functionality in humic substances, in: Humic substances in soil, sediment and water, G. R. Aiken, D. M. McKnight, R. L. Wershaw, P. MacCarthy (Eds.), Wiley, New York, 1985, pp. 561-582.

[16] H. Herzog, P. Burba, J. Buddrus, Quantification of hydroxylic groups in a river humic substance by ${ }^{29}$ Si-NMR, Fresenius J. Anal. Chem., 354, 374 377 (1995).

[17] S. Sachs, M. Bubner, K. Schmeide, G. R. Choppin, K. H. Heise, G. Bernharg, Carbon-13 NMR spectroscopic studies on chemically modified and unmodified synthetic and natural humic acids, $T a$ lanta, 57, 999-1009 (2002).

[18] B. Manunza, S. Deiana, V. Maddau, C. Gessa, R. Seeber, Stability constants of metal-humate complexes: Titration data analyzed by bimodal gaussian distribution, Soil Sci. Soc. Am. J., 59, 15701574 (1995).

[19] J. A. Leenheer, G. K. Brown, P. MacCarthy, S. E. Cabaniss, Models of metal binding structures in fulvic acid from the Suwannee River, Georgia, Environ. Sci. Technol., 32, 2410-2416 (1998).

[20] J. A. Leenheer, T. I. Noyes, Derivatization of humic substances for structural studies, in: Humic substances II. In search of structure, M. H. B. Hayes, P. MacCarthy, R. L. Malcolm, R. S. Swift (Eds.), Wiley, New York, 1989, pp. 257-280.

[21] M. Schnitzer, S. I. M. Skinner, Organo-metallic interactions in soils: 4. Carboxyl and hydroxyl groups in organic matter and metal retention, Soil Sci., 99, 278-284 (1965).

[22] T. Andjelkovic, J. Perovic, M. Purenovic, S. Blagojevic, R. Nikolic, D. Andjelkovic, A. Bojic, Spectroscopic and potentiometric studies on derivatized natural humic acid, Anal. Sci., 22, 1553-1558 (2006).

[23] B. D. Hosangadi, R. H. Dave, An efficient general method for esterification of aromatic carboxylic acids, Tetrahedron Lett., 37, 6375-6378 (1996).

[24] R. S. Saar, J. H. Weber, Complexation of cadmium(I1) with water- and soil-derived fulvic acids: effect of $\mathrm{pH}$ and fulvic acid concentration, Can. J. Chem., 57, 1263-1268 (1979).

[25] S. Y. Choi, H. Moon, S. Jun, K. H. Chung, Comparison of the stability constants of $\mathrm{Cd}(\mathrm{II})-, \mathrm{Cu}(\mathrm{II})$ and $\mathrm{Pb}(\mathrm{II})$-humate complexes, Bull. Korean Chem. Soc., 15, 581-584 (1994).

[26] A. S. Mathuthu, J. H. Ephraim, Binding of cadmium to Laurentide fulvic acid. Justification of the functionalities assigned to the predominant acidic moieties in the fulvic acid molecule, Talanta, 42, 1803-1810 (1995).

[27] G. Abate, J. C. Masini, Acid-basic and complexation properties of a sedimentary humic acid. A study on the barra bonita reservoir of Tiete River, Sao Paulo State, Brazil, J. Braz. Chem. Soc., 12, 109116 (2001).

[28] D. A. Dzombak, W. Fish, F. M. M. Morel, Metalhumate interactions. 1. Discrete ligand and continuous distribution models, Environ. Sci. Technol., 20, 669-674 (1986). 
[29] J. C. Westall, J. D. Jones, G. D. Turner, J. M. Zachara, Models for association of metal ions with heterogeneous sorbents. 1. Complexation of $\mathrm{Co}$ (II) by Leonardite humic acid as a function of $\mathrm{pH}$ and $\mathrm{NaClO}_{4}$ concentration, Environ. Sci. Technol., 29, 951-959 (1995).

[30] G. Scatchard, The attraction of proteins for small molecules and ions, Ann. N. Y. Acad. Sci., 51, 660672 (1949).

[31] R. F. C. Mantoura, J. P. Riley, The use of gel filtration in the study of metal binding by humic acids and related compounds, Anal. Chim. Acta, 76, 97 106 (1975).

[32] E. M. Perdue, C.R. Lytle, Distribution model for binding of protons and metal ions by humic substances, Environ. Sci. and Technol., 17, 654-660 (1983).

[33] J.P. Gustafsson, Modeling the acid-base properties and metal complexation of humic substances with the Stockholm Humic Model. J. Colloid Interface Sci., 244, 102-112 (2001).

[34] L.K. Koopal, W.H.Riemsdijk, J.C.M. de Wit, M.H. Benedetti, Analytical isotherm equations for multicomponent adsorption to heterogeneous surfaces, J. Colloid Interface Sci., 166, 51-60 (1994).

[35] F. J. Stevenson, A. Fitch, M. S. Brar, Stability constants of $\mathrm{Cu}(\mathrm{II})$-humate complexes: comparison of selected models, Soil Sci., 155, 77-91 (1993).

[36] R. S. Swift, Organic matter characterization, in: Methods of Soil Analysis. Part 3. Chemical Methods, D. L. Sparks, J. M. Bartels, J. M. Bigham, (Eds.), Soil Science Society of America, Madison WI, USA, 1996, pp. 1018-1020.
[37] M. Schnitzer, U. C. Gupta, Determination of acidity in soil organic matter, Soil Sci. Soc. Proc., 27, 274-277 (1965).

[38] E. M. Logan, I. D. Pulford, G. T. Cook, A. B. Mackenzie, Complexation of $\mathrm{Cu}^{2+}$ and $\mathrm{Pb}^{2+}$ by peat and humic acid, Eur. J. Soil Sci., 48, 685-696 (1997).

[39] A. Kaschl, V. Romheld, Y. Chen, Cadmium binding by fractions of dissolved organic matter and humic substances from municipal solid waste compost, $J$. Environ. Qual., 31, 1885-1892 (2002).

[40] A. C. Parmeggiani, J. C. Masini, Evaluating Scatchard and differential equilibrium functions to study the binding properties of $\mathrm{Cu}$ (II) to the surface of mixed species of lyophilized spirulina (cyanobacteria), J. Brazil. Chem. Soc., 14, 416-424 (2003).

[41] F. J. Stevenson, K. M. Goh, Infrared spectra of humic and fulvic acids and their methylated derivatives: Evidence for non-specificity of analytical methods for oxygen-containing functional groups, Soil Sci., 113, 334-345 (1971).

[42] R. S. Saar, J. H. Weber, Lead(II) complexation by fulvic acid: How it differs from fulvic acid complexation of copper(II) and cadmium(II), Geochim. Cosmochim. Acta, 44, 1381-1384 (1980).

[43] F. J. Stevenson, Y. Chen, Stability Constants of Copper(II)-Humate Complexes Determined by Modified Potentiometric Titration, Soil Sci. Soc. Am. J., 55, 1586-1591 (1991). 